\title{
ELT Majors' Cross Sectional Evaluation of Academic Lexical Competence and Performance
}

\author{
Gül DURMUŞOĞLU KÖSE \\ Anadolu University, Eskisehir, Turkey \\ İlknur YUKSEL \\ Anadolu University, Eskisehir, Turkey
}

\begin{abstract}
Academic vocabulary knowledge and use are critical for students' language proficiency and academic achievement. Through the constructs of lexical competence and performance, the multidimensional nature of academic vocabulary and its interrelated components could be described better so that students' development of academic vocabulary knowledge through their education could be revealed effectively. Considering this, the present study aimed to examine the university students' academic lexical competence and performance combing all main dimensions, namely receptive (size; how many words), and productive (use) dimensions. In that way, it was aimed to reveal 371 ELT majors' academic vocabulary development in English as Foreign Language environment through cross-sectional evaluation. Applying multi-test approach, the receptive and productive sub-dimensions were investigated. The results indicated that both academic lexical competence and performance developed through the years. Particularly, a salient jump of size of academic vocabulary from the $1^{\text {st }}$ year to the $2^{\text {nd }}$ year indicated the effect of proficiency and education. In spite of promising increase in the students' academic lexical competence, limited use of academic vocabulary in the essays drew attention. It was observed that the students tend to avoid using academic vocabulary while writing. In this study, the reasons underlying these findings were discussed within related literature.
\end{abstract}

Index Terms — vocabulary knowledge, lexical competence, lexical performance, academic vocabulary

\section{INTRODUCTION}

Vocabulary is widely accepted as the most predominant aspect of language competence (Nation, 1990; Schmitt, 1997; Crossley \& Salsburry, 2010; Mokhtar, 2010) such that second language acquisition is usually regarded as a matter of learning vocabulary (Read, 2000; Meara, 1996; 2002; Nation 2001). As a result of this ever-increasing interest on vocabulary, many theoretical and empirical studies have been conducted particularly since the 1990s (e.g. Laufer \& Nation, 1995; Wesche \& Paribakht, 1996; Nation, 2001; 2005; Meara \& Alcoy, 2010; Coxhead, 2011). These studies have shed light on the nature of vocabulary and revealed that vocabulary knowledge consists of number of dimensions such as receptive and productive (Nation, 2001; Webb, 2005). Thus, vocabulary knowledge is conceptualized not only as the numbers of words learners know (i.e. vocabulary size) but also how well these words are mastered (i.e. depth of vocabulary) and used (i.e. productive vocabulary) (Read, 2000; Meara, 2002; Schmitt et al, 2010). Along with this enhanced understanding, the concepts of lexical competence and performance in second language have been prominent to describe this multi-dimensional nature of vocabulary knowledge (Meara, 1996; Laufer \& Nation, 1999; 1995; Laufer, et al. 2004; Nation, 2001; Henriksen, 1999; Webb, 2005). Through these umbrella concepts, vocabulary knowledge has been described from global perspective, examining different dimensions (Henriksen, 1999; Zareva, 2005). Yet, the focus has been mostly on general vocabulary, particularly high frequent vocabulary that are more common in discourse with $2000^{\text {th }}$ frequency band (Nation, 1990; 2001; Laufer \& Nation, 2004; Webb, 2005; Zareva, 2005).

In fact, for the higher education students, advanced students, academic vocabulary is critical for academic achievement as well as understanding the academic discourse at schools (Corson, 1997; Coxhead, 2001, 2011; Nation, 2001; Horst et al, 2005; Hyland \& Tse, 2007) but there is a paucity in the studies describing second language learners', especially English as a Foreign language learners', academic lexical competence and performance (Hyland \& Tse, 2007; Hancioglu et al, 2008; Coxhead, 2000; Chen \& Ge, 2007; Vongpumivitch et al, 2009). These few studies have investigated the academic vocabulary from a limited perspective, focusing on only one or two dimensions. For instance, Zhou (2010) investigated the receptive and productive academic vocabulary of tertiary students but called for more detailed studies on especially academic lexical performance. Thus, it is essential to handle the academic lexical competence and performance combining all main dimensions, namely receptive (size; how many words), and productive (use) dimensions to reveal the academic vocabulary development of students at higher education in detail.

Addressing to this need of global large-scaled investigation of academic vocabulary knowledge and based on the premise that vocabulary is a multidimensional concept; the present study aimed to examine the academic lexical competence and performance of ELT majors in English as a foreign language (EFL) classroom setting at Anadolu University in Turkey. In line with this aim, the following research questions were addressed: 


\section{What are Turkish ELT majors' academic lexical competence and performance?}

a. What is Turkish ELT majors' size of academic vocabulary?

b. What is Turkish ELT majors' academic vocabulary knowledge in terms of receptive and productive dimensions? c. What is Turkish ELT majors' academic lexical performance?

d. Do the participants' academic lexical competence and performance differ during their higher education?

Through this study, it is hoped to get better insight about the multidimensional nature of vocabulary knowledge and thus second language vocabulary learning. Besides, it is hoped to probe the neglected aspects in vocabulary research such as global descriptions of academic lexical competence and performance.

\section{ACADEMic LeXical Competence And Performance}

Academic vocabulary is defined as common across academic disciplines (Coxhead, 2000) and they comprise some 8\%-10\% of running words in academic texts (Nation and Coxhead, 2001). These words are important due to the role they play in defining, delineating, advancing and assessing abstract entities such as theories, arguments and hypotheses (the italicized words are AWL words) (Cobb \& Horst, 2004). However, academic vocabulary is widely considered to cause difficulties for ESL and/or EFL learners (Chung \& Nation, 2003; Cobb \& Horst, 2004; Coxhead \& Nation, 2001; Coxhead, 2000). The features of academic vocabulary, such as abstractness, polysemy (i.e. one form can have several meanings), and homonymy, (i.e. one meaning can be represented by different forms) (Nation, 2001) can cause troubles for L2 learners to learn and use the academic vocabulary. Especially, abstractness and polysemic nature of academic vocabulary can be problems. Specifically, regarding abstractness, the problem occurs when the meanings of new academic words do not match with the ones in L1, for which semantic representations have already developed. Additionally, the learners can have difficult to learn and use the academic words due to polysemy and homonymy (Schmitt \& McCarthy, 1997). In spite of all these probable difficulties, learners attempt to build a repertoire of specialized academic words in addition to their existing basic or general service vocabulary for their academic achievement (Hyland \& Tse, 2007).

Referring the crucial role of academic vocabulary knowledge, variety of vocabulary lists have been compiled from corpora, or collections, of academic texts to identify the most valuable words in academic contexts. For decades, University Word List (Xue \& Nation, 1984) has been cited and then the Academic Word List (AWL) (Coxhead, 2000) has been used as the most recent compilation in literature. The AWL contains 570 word families, beyond the first 2000 words of English in General Service List (GSL) described by West (1953). This list is accepted as contributory and even authoritative in academic vocabulary research. Many studies have been conducted in different aspects such as the features, distributions and functions of words in the AWL and the usefulness and high coverage of the list have been widely agreed (Murphy \& Kandil, 2003; Hyland \& Tse, 2007; Vongpumivitch et al, 2009; Ming-Tzu and Nation, 2004; Tsubaki, 2004; Hyland \& Tse, 2007; Billuroglu \& Neufeld, 2005; Hancioglu et al, 2008). Moreover, the applicability of AWL to specific fields has been examined (Chung \& Nation, 2003; Chen and Ge, 2007; Mudraya, 2006).

As a result of such studies, it has been agreed that academic vocabulary, specifically the ones from the AWL, has key role on the academic achievement for L2 students at the tertiary level (Coxhead \& Nation, 2001; Cobb \& Horst, 2004; Laufer \& Nation, 1995). The findings of these studies commonly pointed out that the students who could use academic vocabulary effectively, achieved good academic performance. Thus, to determine academic lexical competence and performance could be a valuable step forward to evaluate teaching and learning processes.

\section{MethodolOGY}

\section{A. Research Design}

The present study aimed to describe the overall state of advanced Turkish ELT majors' academic lexical competence and performance. In line with this aim of the study, the quantitative research design was used. To obtain the best data that can address each research question, under the principles of descriptive research method, cross-sectional design was preferred. This design is considered as appropriate to the scope of the present study since academic lexical competence and performance are apt to develop over a period of time across varying L2 learning stages. Moreover, through crosssectional data collection procedure, different learners can be studied at different stages of development, different points of progression through time, which can be considered as if they were cross-sections of the same learners spread out through time (Creswell, 2005).

\section{B. Participants}

The population of this study consisted of Turkish students attending to the $1^{\text {st }}$ year first semester, $1^{\text {st }}$ year second semester, $2^{\text {nd }}$ year, $3^{\text {rd }}$ year and $4^{\text {th }}$ years at Education Faculty, at the Department of English Language Teaching at Anadolu University in Eskisehir. Including two semesters from the $1^{\text {st }}$ year, it was aimed to reveal the development of the participants' academic lexical competence and performance from the very beginning to the end of their higher education. It was considered that the findings obtained from the students who just enrolled to the university can reveal the Turkish ELT majors' starting vocabulary knowledge level before higher education and make sense of any possible 
vocabulary development till $4^{\text {th }}$ year throughout higher education. These students were the candidates of English teachers and they had been learning English as a Foreign Language.

To describe the academic lexical competence and performance of ELT majors comprehensively, the instruments were delivered to all students. Out of 400 students, 371 students completed all instruments and included in the analysis.

\section{Instruments}

To have better insights of interrelated dimensions of lexical knowledge, it is essential to use different measures (Laufer \& Nation, 2004), thus, 'multiple test approach' was adapted in this study. Using a battery of tests, different aspects of academic vocabulary knowledge were measured in order to provide a comprehensive picture of learners' vocabulary at different stages of language development.

In this sense, three different instruments were used to address each dimension of academic lexical competence and performance. Firstly, to measure the receptive dimension of academic lexical competence, namely the size, the academic vocabulary section of the new version of Vocabulary Level Test developed by Schmitt et al. (2001) was applied. This test involves all five word frequency levels ranging $2000^{\text {th }}, 3000^{\text {th }}, 5000^{\text {th }}, 10000^{\text {th }}$ as well as academic vocabulary. The academic words questioned in the test were selected from the AWL and the test items are arranged into clusters containing six words and three definitions to be matched. For scoring the VLT, each correct definition is scored as one point. Each of the four frequency level section and academic vocabulary section contain 30 target items. Therefore, the maximum score for the academic vocabulary section is 30 (i.e. $6 \times 5$ ).

To evaluate the participants' academic lexical performance, argumentative writing task was given and lexical frequency profile (LFP) analysis was conducted. Considering the operability, functionality, practicality of Lexical Frequency Profile and accounting of the findings related to its reliability and validity (Morris \& Cobb, 2004; Laufer, 2005), in this study, Vocabprofile, which is available on www.lextutor.ca/ was used to determine the participants' lexical use. To operate the LFP test, Vocabprofile, a text was typed into the computer program and text analysis, consisting the percentages of type/token ratio and word families, were supplied according to four frequency levels, according to $1 \mathrm{k}$ (1 to 1000), $2 \mathrm{k}$ (1001 to 2000), off-list and AWL words. For the scope of the study, the results on the use of academic vocabulary were taken into account but the distributions of $1 \mathrm{k}+2 \mathrm{k}$ and off-list were discussed to make sense of the proportion of academic vocabulary use.

The measurements that are explained above have specific sections addressing to the academic vocabulary. However, to further discuss the academic lexical competence and performance, a test measuring the receptive (i.e. recognition) and productive (i.e. use) dimensions together was developed by the researchers for this study. Through this test, it was aimed to evaluate participants' recognition and production of academic vocabulary with one accord. The results of this test were considered to bridge the academic lexical competence and performance. Adapting the format of the Vocabulary Knowledge Scale developed by Wesche and Paribakht (1996), a Test of Academic Vocabulary (TAV) with 30 academic words, which were selected systematically from the AWL, were developed and validated (.80 coefficient value). A sample item from the test was given in the following:

\section{e.g. resolution}

a. I have never seen this word before

b. I have seen this word before but I don't know what it means

c. I have seen this word before and I think it means

d. I can use this word in a sentence (if you answer this part, also answer part c)

\section{Data Collection and Analysis}

The tests were applied at a regular class time with the permission of the class teacher by the researcher. Before the applications, the aim and content of the study were explained and the students were asked to sign the consent form to participate in the study voluntarily. After all instruments were collected in 2009-2010 spring academic term, the data preparation procedure was started. Firstly, all collected data was classified into five groups according to the year the participants attend. Then, all four instruments were matched together for each participant. In this way, the missing cases; the one who did not complete all four instruments and/or wrongly completed, were extracted. As a result, 29 cases were discarded from the total sample of 400 students so four instruments collected from 371 students were analyzed in the present study.

The distribution of the number of participants explaining the collected data and the ones involved in the analysis are given in the Table 1 .

TABLE 1.

DISTRIBUTION OF THE PARTICIPANTS IN TERMS OF YEARS AND COLLECTED INSTRUMENTS

\begin{tabular}{lllll}
\multicolumn{2}{c}{ DISTRIBUTION OF THE PARTICIPANTS IN TERMS OF YEARS AND COLLECTED INSTRUMENTS } \\
\hline & VLT & TAV & ESSAY & In the Analysis \\
\hline $\mathbf{1}^{\text {st }}$ year first sem & 49 & 52 & 50 & 49 \\
$\mathbf{1}^{\text {st }}$ year second sem & 70 & 75 & 78 & 70 \\
$\mathbf{2}^{\text {nd }}$ year & 83 & 84 & 83 & 83 \\
$\mathbf{3}^{\text {rd }}$ year & 89 & 95 & 89 & 89 \\
$\mathbf{4}^{\text {th }}$ year & 80 & 86 & 83 & 80 \\
TOTAL & 322 & 323 & 326 & 371 \\
\hline
\end{tabular}


The collected data was analyzed through 15.0 version of Statistical Package of Social Science (SPSS). In line with the research questions, statistical calculations were performed. By means of descriptive statistics, a general picture of the participants' academic vocabulary size (VLT), receptive and productive academic vocabulary knowledge (TAV), lexical use (LFP) were determined, then one-way ANOVA analysis was used for between and within group comparisons. As a post hoc test to determine the group causing any significance, Tukey HSD test was employed.

\section{RESULTS}

\section{A. Academic Lexical Competence}

Regarding the participants' academic lexical competence, firstly their size of academic vocabulary was investigated through the academic vocabulary section of Vocabulary Level Test (VLT). The obtained findings are presented and illustrated in Table 2 and Figure 1.

TABLE 2:

MEANS AND SDS OF THE FIVE FREQUENCY BANDS FOR ALL GROUPS OF THE PARTICIPANTS

\begin{tabular}{|c|c|c|c|c|c|c|c|c|c|c|}
\hline & \multicolumn{2}{|c|}{$\begin{array}{l}1^{\text {st }} \text { year first sem. } \\
(n=49)\end{array}$} & \multicolumn{2}{|c|}{$\begin{array}{l}1^{\text {st }} \text { year second sem } \\
(\mathrm{n}=70)\end{array}$} & \multicolumn{2}{|c|}{$\begin{array}{l}2^{\text {nd }} \text { year } \\
(n=83)\end{array}$} & \multicolumn{2}{|c|}{$\begin{array}{l}3^{\text {rd }} \text { year } \\
(n=89)\end{array}$} & \multicolumn{2}{|l|}{$\begin{array}{l}4^{\text {th }} \text { year } \\
(n=80)\end{array}$} \\
\hline & Mean & SD & Mean & SD & Mean & SD & Mean & SD & Mean & SD \\
\hline AWL & 24,71 & 5,362 & 26,91 & 3,082 & 27,90 & 3,055 & 26,96 & 3,766 & 27,40 & 2,791 \\
\hline
\end{tabular}

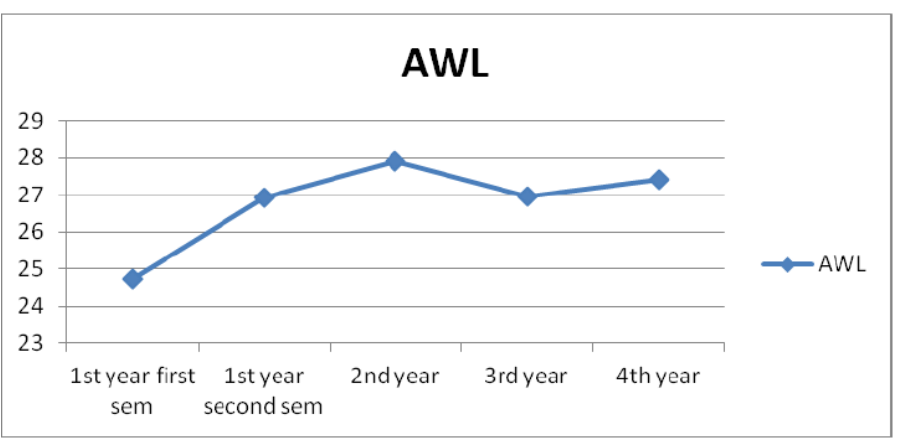

Figure 1. The Distribution of Size of Academic Vocabulary for all groups

The findings related to the size of vocabulary knowledge indicated that there is a salient increase in the academic vocabulary size from the $1^{\text {st }}$ year first semester to the $2^{\text {nd }}$ year, yet a decrease occurred at the $3^{\text {rd }}$ year and followed with a kind of plateau at the $4^{\text {th }}$ year. The outperformance of the $2^{\text {nd }}$ year students $($ mean=27,90) was followed with slight difference by the $4^{\text {th }}$ year students (mean=27,40). With close values, the $3^{\text {rd }}$ year $(26,96)$ and the $1^{\text {st }}$ year $(26,91)$ students were in pursuit of these two groups. Among these groups, the $1^{\text {st }}$ year first semester students were detected to know less academic words in the test.

To further examine whether the differences among groups are statistically significant, one-way ANOVA analyses were employed with the mean scores. Accordingly; there is a significant difference among the five groups of participants since $P=, 000<, 05$. Thus, it could be claimed that the participants' size of academic vocabulary differed significantly in terms of years. Tukey HSD test was also applied as post hoc analysis in order to make comparisons across the five groups to detect the source of significant difference. The results indicated that the $1^{\text {st }}$ first semester students got the lowest score from other groups and this caused significant difference.

To deepen the investigation on the academic lexical competence and to touch upon the academic lexical performance in terms of sentence-based use of academic vocabulary, the scores of Test of Academic Vocabulary were analyzed. The obtained findings across the five participant groups are presented in Table 3 and Figure 2.

TABLE 3.

MEANS AND SDS OF TEST OF ACADEMIC VOCABULARY

\begin{tabular}{|c|c|c|c|c|c|}
\hline $\begin{array}{l}\text { Test of Academic } \\
\text { Vocabulary }\end{array}$ & $\mathbf{N}$ & Mean* & SD & Min & Max \\
\hline $1^{\text {st }}$ year first sem. & 49 & 18,71 & 11,498 & 0 & 54 \\
\hline $1^{\text {st }}$ year second sem. & 70 & 34,06 & 9,570 & 15 & 53 \\
\hline $2^{\text {nd }}$ year & 83 & 34,76 & 6,402 & 18 & 55 \\
\hline $3^{\text {rd }}$ year & 89 & 35,12 & 5,703 & 20 & 54 \\
\hline $4^{\text {th }}$ year & 80 & 36,69 & 8,881 & 20 & 54 \\
\hline TOTAL & 371 & 33,01 & 9,992 & 0 & 55 \\
\hline
\end{tabular}

*The mean score is calculated out of 60 as the maximum score of TAV 


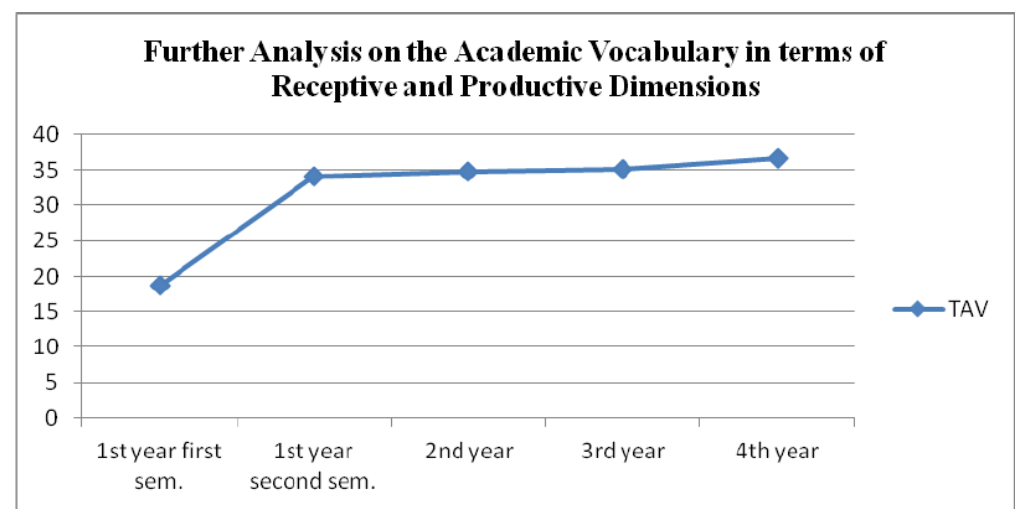

Figure 2: Development of Academic Vocabulary in terms of Receptive and Productive Dimensions across the years.

As can be seen at Table 3 Figure 2, there was again a gradual increase at the participants' academic vocabulary. The $1^{\text {st }}$ year first semester students got the lowest score $(18,71)$, after a sharp increase, it was followed with $1^{\text {st }}$ year second semester students $(34,05)$. On contrary to the participants' size of academic vocabulary, a plateau was observed at $2^{\text {nd }}$ and $3^{\text {rd }}$ year with quite close mean values. At the $4^{\text {th }}$ year, a slight increase at the participants' academic vocabulary knowledge was seen. This finding implied that the university education increased the participants' academic vocabulary knowledge receptively and productively, particularly the increase at the $1^{\text {st }}$ year first semester indicated that the exposure to academic vocabulary yielded enhancement at academic vocabulary knowledge. However, the plateau at $2^{\text {nd }}$ and $3^{\text {rd }}$ years as well as slight increase at $4^{\text {th }}$ year implied that the participants' academic vocabulary knowledge remained more or less the same throughout their education.

For further analysis on these findings, one-way ANOVA was conducted. The findings on between and within group comparison also supported that the participants' academic vocabulary knowledge was sensitive to the years they attend, since it was found that the differences were statistically significant $(F=43,070, P=, 000<, 05)$. In other words, the participants' academic vocabulary knowledge differed in terms of the years they attend. As a result of Tukey HSD test, $1^{\text {st }}$ year first semester was found to be the source of difference $(P=, 000<, 05)$. The mean values of this group indicated that the lowest performance of this group caused the difference.

\section{B. Academic Lexical Performance}

In addition to the participants' sentence-based use of academic vocabulary in TAV, the outputs of participants' essays were analyzed in detail as indicator of their academic lexical performance. After all essays were submitted to software program, the outputs involving mean values for lexical frequency profile of each participant were obtained and an overall mean value for each year was calculated. To discuss the use of academic vocabulary in the essays more thoroughly, the proportions of high frequent vocabulary (K1_K2) and off-list vocabulary (i.e. low frequent and jargons) were also analyzed. Accordingly, the descriptive data on the participants' lexical use are presented in Table 4.

TABLE 4:

DESCRIPTIVE STATISTICS FOR ACADEMIC VOCABULARY USE OF ALL GROUPS OF THE PARTICIPANTS

\begin{tabular}{|c|c|c|c|c|c|c|c|c|c|c|}
\hline & \multicolumn{2}{|c|}{$\begin{array}{l}1^{\text {st }} \text { year first sem. } \\
(\mathrm{n}=49)\end{array}$} & \multicolumn{2}{|c|}{$\begin{array}{l}1^{\text {st }} \text { year sec. sem. } \\
(\mathrm{n}=70)\end{array}$} & \multicolumn{2}{|c|}{$\begin{array}{l}2^{\text {nd }} \text { year } \\
(n=83)\end{array}$} & \multicolumn{2}{|c|}{$\begin{array}{l}3^{\text {rd }} \text { year } \\
(n=89)\end{array}$} & \multicolumn{2}{|c|}{$\begin{array}{l}4^{\text {th }} \text { year } \\
(n=80)\end{array}$} \\
\hline & Mean & SD & Mean & SD & Mean & SD & Mean & SD & Mean & SD \\
\hline K1_K2 & 87,30 & 29,797 & 95,18 & 1,788 & 95,10 & 2,534 & 94,65 & 2,184 & 94,93 & 2,137 \\
\hline ESSAY_AW & 1,50 & 1,181 & 2,79 & 1,131 & 3,27 & 1,879 & 3,68 & 1,710 & 3,73 & 1,646 \\
\hline OFF_LIST &, 86 & ,786 & 2,09 & 1,165 & 1,44 & 1,212 & 1,79 & 1,161 & 1,67 & 1,245 \\
\hline
\end{tabular}

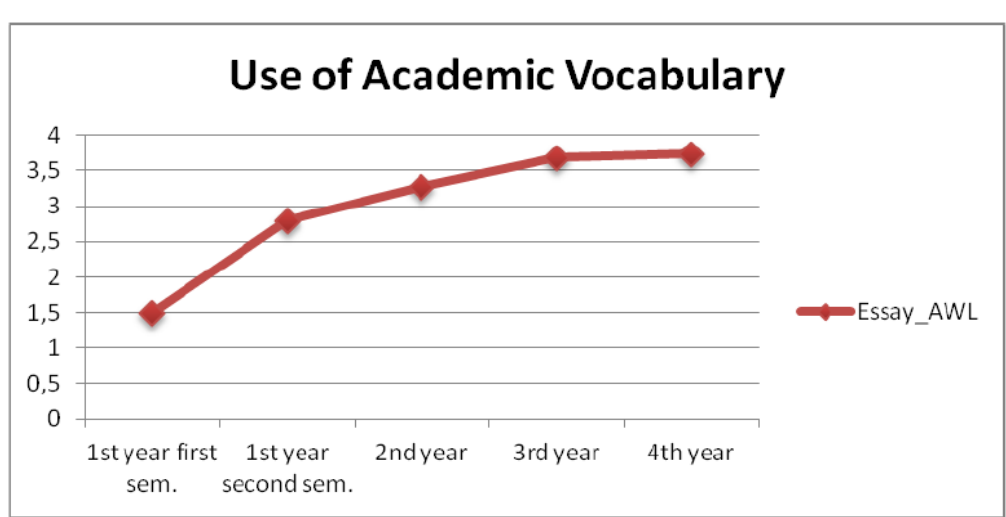

Figure 3. Development of Use of Academic Vocabulary across Five Participant Groups 
As the mean and standard deviation values in Table 4 show that there is an almost gradual increase in use of vocabulary types across the years. The overall picture the analyses have revealed is that there was an overwhelming use of high frequent vocabulary in the essays while the increase in academic and off-list vocabulary was in very small proportion.

However, the results about the use of academic vocabulary seem promising as there was a constant increase in the use of academic vocabulary across the years. Starting from the very low proportion at the $1^{\text {st }}$ year first semester $($ mean $=1,50)$, it increased incrementally at $1^{\text {st }}$ year second semester $\left(\right.$ mean=2, 79), $3^{\text {rd }}$ year $(\mathrm{mean}=3,27), 3^{\text {rd }}$ year (mean $=3,68)$ respectively and received the peak at $4^{\text {th }}$ year with 3,73 . Thus, it can be tentatively claimed that the increase in the productive academic vocabulary is the reflection of the language improvement and academic vocabulary knowledge. As participants' proficiency in language use increased through their tertiary education, they used more academic words.

To determine whether the differences at the mean values for each vocabulary category are statistically significant or not, one-way ANOVA was employed. The results of one-way ANOVA indicated that there were significant differences on each vocabulary category across five participant group $(P=, 000<, 05)$. This finding showed that the lexical use of the vocabulary types (i.e. high frequent, academic vocabulary and off-list) differed in terms of the years the participants attend. The $1^{\text {st }}$ year first semester was again found as the group caused this difference as a result of post hoc test.

Overall, the findings on Turkish ELT majors' academic lexical competence and performance indicated that there were increases in the participants' academic vocabulary knowledge in terms of three indices, namely; size, receptive and productive dimensions as well as use. However, the saliency of these increases differed in a way that the development of receptive and productive of academic vocabulary was more striking. As the common point among three indices there was a plateau at $1^{\text {st }}$ year second semester, $2^{\text {nd }}$ year and $3^{\text {rd }}$ year, even a decrease at $3^{\text {rd }}$ year for size of academic vocabulary. Comparing the values for $1^{\text {st }}$ year first semester with $4^{\text {th }}$ year, it could be claimed that the participants' academic lexical competence and performance increased throughout their university education. These findings were also supported with the results of one-way ANOVA tests as explained for each dimension above.

\section{DisCUSSION AND CONCLUSION}

Within a conceptual three-dimensional framework of second language academic lexical competence and performance, the learners' academic vocabulary knowledge profiles as well as the development of the academic vocabulary dimensions are investigated through multiple test approach.

The findings of academic vocabulary size revealed a jump from the $1^{\text {st }}$ year first semester to the $1^{\text {st }}$ year second semester and intervened with the decrease at $3^{\text {rd }}$ year. Thus, it could be claimed the effect of proficiency throughout education is salient for the development of academic vocabulary. This growth of vocabulary size could be also explained with the increasing language proficiency as in Fan's (2000) study and repeated exposure to the target vocabulary as in Goldberg et al.'s research (2008). Although this growth proportion is too ambitious for academic vocabulary, these empirical findings on the vocabulary growth could explain the jump from the $1^{\text {st }}$ year first semester to $2^{\text {nd }}$ year in the present study.

Moreover, many researchers studying on the L2 learners' academic vocabulary knowledge emphasized the effect of exposure to learn academic vocabulary (Coady, 1993; Laufer, 1997, 1998; Laufer \& Nation, 1995). If students read less, they will encounter fewer words, and it will eventually hamper their development of academic vocabulary. Thus, it can be claimed that the acquisition of academic vocabulary is concerned with what words learners are exposed to. For instance, despite the gaps in learners' frequent vocabulary knowledge, in an academic learning context, this leaner might primarily acquire words that are generally less frequent but more frequent in the academic setting (Chapelle, 1998; Coxhead, 2000). In the same vein, Milton (2007) explained how L2 learners could learn academic and/or less frequent words while having knowledge gaps in high frequency words with the issue of language exposure in foreign language contexts. Then, he suggested that in such language contexts, words are not acquired according to frequency of occurrence but learned thematically from course books, reading texts and lectures. In this respect, the participants' linear increase of academic vocabulary throughout their education can be explained. In case that the learners are not willing to learn or the instructors or the content of the courses do not force to learn and use more vocabulary, vocabulary acquisition, can be hampered. Moreover as Aziez' (2011) study revealed that textbooks have a low coverage of the words beyond 2000 (i.e. high frequent ones). So the learners' exposure to the academic vocabulary and/or lowfrequent vocabulary remains limited. The learners could not get more input to improve their academic vocabulary knowledge. This could explain the decrease of academic vocabulary sizes of the learners at the $3^{\text {rd }}$ and restricted increase at the $4^{\text {th }}$ year. It may be the case that he learners at these years did not encounter new/more academic vocabulary that could enhance their vocabulary size.

Regarding the academic lexical performance, it could be claimed that there was a consistent increase across the five participant groups. The use of academic vocabulary gained acceleration from the $1^{\text {st }}$ year first semester to the $4^{\text {th }}$ year. The effects of academic language exposure and requirements of the courses contents, as valid for academic lexical competence, could be also considered for this issue. The participants got motivated and in fact they were required to use academic vocabulary more and more throughout their education; either in their courses for demos, presentations, and participations; or in their exams for writing essay types. In spite of promising increase of academic vocabulary across 
the years at the $2^{\text {nd }}$ year, their lexical use appeared very limited. This finding is not surprising at all since similar cases have been observed in other studies. For instance; Laufer (1991) found that university students did not significantly increase their productive vocabulary when there was no systematic instruction to vocabulary learning. She emphasized that learners tend to favor simple, general and frequent words in production. In addition, Laufer and Nation (1999) stated that a learner may be able to produce a sentence with an infrequent word when required to do so by the teacher but be reluctant to use when left to his own devices, as in composition writing task and choose to use a simpler more frequent word of a similar meaning. Such reluctance is often a result of uncertainty about the word's usage and lack of confidence caused due to limited L2 vocabulary. In this regard, Read (2000) also pinpointed the learners' avoidance and paraphrasing strategies not to use low frequent vocabulary. Crossley (2009) explained the reliance of high frequent vocabulary in writing referring the discrepancy between L1 and L2 vocabulary knowledge. Due to limited vocabulary knowledge in L2 in comparison to their native tongue, the learners tend to use more words of general rather than specific meaning. The discrepancy between the academic receptive and productive vocabulary in this study was also observed at Horst and Collins' (2006) study in which learners did not incorporate less frequent vocabulary into their written productions in spite of intensive instruction.

Thus, in the context of the present study, the participants preferred to explain their arguments mostly with high frequent vocabulary, in spite of tendency at $1^{\text {st }}$ and $2^{\text {nd }}$ year, the $3^{\text {rd }}$ and $4^{\text {th }}$ the participants did not take risk although their exposure to academic vocabulary and ELT specific words are supposed to be higher through their courses and requirements. Nonetheless, the consistent increase of academic vocabulary use across the years implied promising development of lexical use. Considering the fact that there was no special explicit academic vocabulary teaching in the courses, the increase in the use of academic vocabulary; 1,29 points from $1^{\text {st }}$ year first semester to $1^{\text {st }}$ year second semester, and approximately 0,5 points per year) throughout the years seemed promising.

\section{CONCLUSION}

Through the cross-sectional investigation of academic vocabulary in terms of lexical competence and performance dimensions, the present study attempted to reveal the English majors' academic vocabulary development through their education. Considering the findings, it could be concluded that both academic lexical competence and performance developed through the years. Thus, the salient effect of proficiency was observed for academic vocabulary development. However, the findings on the fluctuation at academic lexical competence, that is; there was a jump of academic vocabulary size and receptive-productive knowledge from the $1^{\text {st }}$ year first semester to the following years but an intervention at $3^{\text {rd }}$ and $4^{\text {th }}$ year, was striking. These findings could motivate the revision of academic vocabulary exposure and instruction at these years. In addition, the development of academic lexical performance of the participants through the years was obtained as more consistent, yet the proportion of academic vocabulary use in academic essays appeared very limited. Thus, the findings pointed out the ELT majors' tendency to avoid using academic vocabulary while writing. Although they could recognize most of the academic vocabulary, they did not use them; they preferred to explain their arguments with higher frequent words.

The findings of this study pointed the ELT majors' limited academic vocabulary use and hesitating development of academic lexical competence. Considering the critical role of academic vocabulary for the university students, especially the English Language teachers, the explicit and implicit instruction on academic vocabulary or integrating academic vocabulary practice into academic writing and reading courses could be suggested. Moreover, the findings of the present study could contribute to revise and improve the EAP programs since the academic vocabulary is one of the basic component of such programs.

Additionally, it should be claimed that this study is just one step to grasp the nature of vocabulary, particularly academic vocabulary. Further studies on academic vocabulary in conjunction with general vocabulary knowledge could shed more light on the vocabulary development of university students. Besides, other components of academic vocabulary such as semantic and discourse, could be involved to step further the research on academic vocabulary.

\section{ACKNOWLEDGEMENT}

This study is part of an unpublished doctorate thesis, which was funded by the Scientific Research Unit of Anadolu University, Eskisehir, Turkey.

\section{REFERENCES}

[1] Aziez, F. (2011). Examining the Vocabulary Levels of Indonesia's English National Examination Texts. Asian EFL Journal. Vol. 51. 1-14.

[2] Billuroğlu, A., \& Neufeld, S. (2005). The Bare Necessities in Lexis: A new perspective on vocabulary profiling. Retrieved from<http://lextutor.ca/vp/BNL_Rationale.doc>. Retrived on April, 2011.

[3] Chen, Q., \& Ge, G. (2007). A corpus-based lexical study on frequency and distribution of Coxhead's AWL word families in medical research articles (RAs). English for Specific Purposes, Vol. 26, p. 502-514.

[4] Chung, T. M., \& Nation, P. (2003). Technical vocabulary in specialised texts. Reading in a Foreign Language. Vol. 15(2). Retrieved from http://nflrc.hawaii.edu/rfl/October2003/chung/chung.htm, on May, 2011.

[5] Cobb, T. \& Horst. M. (2004). Is there a room for an academic word list in French? In Bogaards, Paul(Editor). Vocabulary in a Second Language. Selection, Acquisition, and Testing.15-37. 
[6] Corson, D. (1997). The Learning and Use of Academic English Words. Language Learning, 47 (4). pp. 671-718.

[7] Coxhead, A. (2000). A New Academic Word List. TESOL QUARTERLY, 34 (2), 213-238.

[8] Coxhead, A. (2011). Using vocabulary in writing in a second language: Writing from sources. Koln: LAP Lambert Academic Publishing.

[9] Creswell, J.W. (2005). Educational research: Planning, conducting, and evaluating quantitative and qualitative research. Upper Saddle River, NJ: Pearson.

[10] Crossley, S. A., \& Salsbury, T. (2010). Using lexical indices to predict produced and not produced words in second language learners. The Mental Lexicon, 5 (1), 115-147.

[11] Fan, M. (2000). How big is the gap and how to narrow it? An investigation into active and passive vocabulary knowledge of learners. RELC Journal. Vol 31(2). pp. 105-119.

[12] Hancioglu, N., Neufeld, S., Eldridge, J. (2008). Through the Looking Glass and into the Land of Lexicogrammar. English for Specific Purposes. Vol. 27. p. 459-479.

[13] Henriksen, B. (1999). Three dimensions of vocabulary development. Studies in Second Language Acquisition. 21: 303-317

[14] Horst, M., \& Collins, L. (2006). From 'faible' to strong: How does their vocabulary grow? The Canadian Modern Language Review, 63(1), 83-106.

[15] Horst, M., Cobb, T., \& Nicolae, I. (2005). Expanding academic vocabulary with a collaborative on-line database. Language Learning \& Technology, 9(2), 90-110.

[16] Hyland, K. \& Tse, P. (2007). Is there an Academic Vocabulary, TESOL QUARTERLY, Vol. 41: 235- 253.

[17] Laufer, B. \& Nation, P. (1995). Vocabulary size and use: lexical richness in L2 written production. Applied Linguistics, 16: 307-322.

[18] Laufer, B. \& Nation, P. (1999). A Vocabulary size test of controlled productive ability, Language Testing, 16: 33-51.

[19] Laufer, B., Elder, C., Hill, K. \& Congdon, P. (2004). Size and Strength: do we need both to measure vocabulary knowledge?, Language Testing, 21 (2): 201-226.

[20] Meara, P. (1996). The dimensions of lexical competence. In G. Brown, K. Malmkjaer \& J. Williams(Eds.), Performance and competence in second language acquisition (pp:35-53). Cambridge: Cambridge University Press.

[21] Meara, P. (2002) The Rediscovery of vocabulary. Second Language Research. 18, 4: 393-407.

[22] Meara, P. M., \& Olmos Alcoy, J. C. (2010). Words as species: An alternative approach to estimating productive vocabulary size. Reading in a Foreign Language, 22(1), 222-236.

[23] Ming-Tzu, K.W. \& Nation, P. (2004). Homography in the academic word list. Applied Linguistics, 25(3), 291-314.

[24] Mokhtar, A. A. (2010). Achieving Native-like English Lexical Knowledge: The Non-native Story. Journal of Language Teaching and Research, Vol. 1, No. 4, pp. 343-352.

[25] Mudraya, O. (2006). Engineering English: A lexical frequency instructional model. English for Specific Purposes, 25, p. 235256.

[26] Murphy, J. \& Kandil, M. (2003). Word-Level Stress Patterns in the Academic Word List. System, 32 (1). p. 61-74.

[27] Nation, P. (1990). Teaching and Learning Vocabulary: Boston: Heinle \& Heinle.

[28] Nation, I. S. P. (2001). Learning Vocabulary in Another Language. Cambridge: Cambridge University Press.

[29] Nation, P. (2005). Teaching Vocabulary. Asian EFL Journal. Vol. 7 (3). pp. 1-9.

[30] Nation, I.S.P. and Coxhead, A. (2001). The specialised vocabulary of English for academic purposes. In J. Flowerdew and M. Peacock (eds.) Research Perspectives on English for Academic Purposes Cambridge University Press, Cambridge: pp. 252-267.

[31] Read, J. (2000). Assessing Vocabulary, Cambridge: CUP.

[32] Schmitt, N. (1997). 'Vocabulary learning strategies.' In N. Schmitt and M. McCarthy, (Eds.), Vocabulary: Description, Acquisition and Pedagogy 199-227. Cambridge University Press, Cambridge.

[33] Schmitt, N., Ching, Ng, J. W \& Garras, J. (2010). The Word Association Format: Validation Evidence. Language Testing, online. 1-22.

[34] Schmitt, N., Schmitt, D. \& Clapham, C. (2001). Developing and Exploring the Behaviour of Two New Versions of the Vocabulary Levels Test. Language Testing, 18 (1): pp. 55-88.

[35] Schmitt, N., \& McCarthy, M. (Eds.) (1997). Vocabulary: Description, acquisition, and pedagogy. Cambridge: Cambridge University Press.

[36] Tsubaki, M. (2004). A Vocabulary in English for Academic Purposes: A Corpus Study of Journal Articles. retrived from cicero.u-bunkyo.ac.jp/lib/kiyo/fsell2004/159 168.pdf in November, 2009

[37] Webb, S. (2005). Receptive and productive vocabulary learning: The effects of reading and writing on word knowledge. Studies in Second Language Acquisition, 27: 33-52.

[38] Wesche, M. \& Paribakht, T.S. (1996). Assessing second language vocabulary knowledge: Depth versus breadth. Canadian Modern Language Review, 53: 13-40.

[39] West, (1953). A General Service List of English Words, Longman, London

[40] Xue, G., \& Nation, I. S. P. (1984). A university word list. Language Learning and Communication, Vol. 3, p. $215-299$.

[41] Vongpumivitch, V., Huang, J. \& Chang, Y. (2009). Frequency Analysis Of The Words In The Academic Word List (AWL) And Non-AWL Content Words In Applied Linguistics Research Papers. English for Specific Purposes Vol. 28: p. 33-41

[42] Zhou, S. (2010). Comparing Receptive and Productive Academic Vocabulary Knowledge of Chinese EFL Learners. Asian Social Science Vol. 6, No. 10. pp. 14-19

[43] Zareva, A. (2005). Models of lexical knowledge assessment of second language learners of English at higher levels of language proficiency. System, 33: 547-562. 


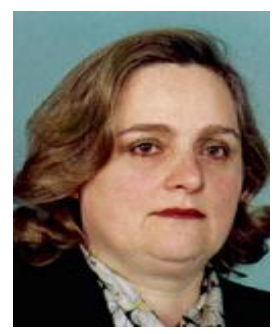

Gül DURMUŞOĞLU KÖSE works as a professor of English Language Teaching at Education Faculty at Anadolu University in Eskisehir, Turkey. She had M.A and PhD degrees from Exeter University in 1980 and 1984. She has been giving lectures on applied linguistics, translation, sociolinguistics, discourse and research skills at Anadolu University. She is currently the dean of Education Faculty. She had many published research papers and she supervised various theses on second language acquisition, language learning and teaching. Her research interest included translation studies, discourse, pragmatics and sociolinguistics.

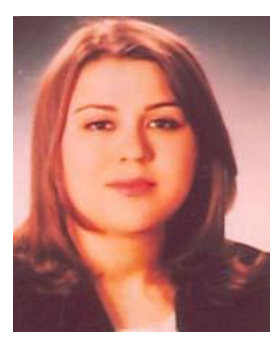

Ilknur YÜKSEL works as a research assistant at Anadolu University at Education Faculty at Anadolu University in Eskisehir, Turkey. She had PhD degree from ELT Department of Anadolu University in 2012. She had different published research papers on second language vocabulary knowledge and teacher education. Her research interests are second language acquisition and teacher education. 